\title{
Application of Artificial Wetlands in Agricultural Wastewater Treatment
}

\author{
Ali Marefat* \\ Graduate Faculty of Environment, University of Tehran, Tehran, Iran \\ *Corresponding author: Ali Marefat, Graduate Faculty of Environment, University of Tehran, Tehran, Iran
}

\begin{tabular}{|c|c|}
\hline ARTICLE INFO & ABSTRACT \\
\hline Received: 彗 February 15, 2021 & $\begin{array}{l}\text { Chemical pesticides are commonly used to increase agricultural yields worldwide, } \\
\text { but these pesticides can be a serious threat to aquatic ecosystems. In recent decades, the }\end{array}$ \\
\hline Published: 畄 February 23, 2021 & use of artificial wetlands to remove chemical toxins from agricultural runoff has become \\
\hline $\begin{array}{l}\text { tation: Ali Marefat. Application of } \\
\text { atificial Wetlands in Agricultural }\end{array}$ & $\begin{array}{l}\text { plant and system that can be applied in artificial wetlands to remove organic and toxic } \\
\text { material form agriculture wastewaters. }\end{array}$ \\
\hline
\end{tabular}

Wastewater Treatment. Biomed J Sci \& Tech Keywords: Agriculture Drainage; Artificial Wetland; Duckweek; Artificial Wetlands

Res 34(1)-2021. BJSTR. MS.ID.005508.

\section{Mini Review}

Artificial wetlands are built by humans to treat municipal, industrial, agricultural and flood wastewater. These wetlands are classified into 3 types of artificial wetland systems with horizontal flow, vertical flow and composite depending on the type of sewage flow in it. In these wetlands, it is possible to use plants such as reeds and halophytes. After crossing the wetland, due to their long residence time, the wastewater loses a significant amount of its pollutants by plants. The main open drainage can be used to build artificial wetlands. For this purpose, instead of an excavator for dredging, new moving devices should be used so that the roots of plants such as straw, water lilies and halophytes are not cut from the roots. Research findings reveal that artificial wetlands are able to significantly separate groups of chemical toxins related to Organchlorine, Strobilurin, strobin, organophosphate and pyrethroids from the effluent. At the same time, artificial wetlands are incapable of removing the chemical toxins triazinone, aryloxy alkaline acid and urea [1]. It is noteworthy that the density of vegetation in artificial wetlands is very effective in removing chemical toxins.

\section{Duckweek}

Duckweeks are small floating plants that grow in nutrientrich environments (nitrogen and phosphate). These micro-plants are able to grow in a wide range of temperatures, diffusions and nutrient levels. In addition, Duckweeks are considered as a suitable food source for aquaculture and animals due to their low fiber content (less than 5\%) and high protein content (10 to 40\%). Also, treatment systems that use duckweeks are $20 \%$ less likely to be evaporated. In Egypt, a study was conducted to investigate the ability of organic matter and ammonium to be removed by artificial wetlands that use micro duckweeks instead of common vegetation. For this purpose, single, double and triple wetlands were designed experimentally and their performance was compared with each other. The results showed that duckweeks are able to remove considerable amount of organic matter (both soluble and insoluble phases) and also urea [2].

\section{DHS}

According to a DRI report, about 7 billion cubic meters of agricultural wastewater ( $40 \%$ of the total) is recycled directly by mixing with the the Nile River, which could reach 11 billion cubic meters by 2017 [3]. However, due to discharging of industrial and domestic wastewater into drainage channels, the possibility of further reuse of wastewater has been seriously challenged. To solve this problem, agricultural drains must be treated. A variety of methods have been proposed for the treatment of agricultural effluents, including:
a) Activated sludge process
b) Trickling filter
c) Aerobic lagoons 


\section{d) Anaerobic lagoons \\ e) Artificial wetlands}

The Downflow hanging sponge system (DHS) method, which is based on aerobic biological treatment, can be used. Inside the DHS reactor, polyurethane sponges are used as a medium to store microbial biomass. The effluent drips from the top of the reactor and is filtered by microorganisms inside or on the surface of the sponges as it moves to the bottom of the reactor. The main advantage of the DHS method is that although it is an aerobic process, it does not require aeration. In addition, this method is very suitable for reducing COD, ammonium and fecal coliforms.

ISSN: 2574-1241

DOI: $10.26717 /$ BJSTR.2021.34.005508

Ali Marefat. Biomed J Sci \& Tech Res

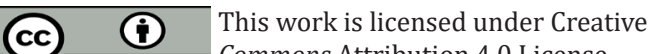
Commons Attribution 4.0 License

Submission Link: https://biomedres.us/submit-manuscript.php

\section{References}

1. Vymazal Jan, Brezinova Tereza (2015) The use of constructed wetlands for removal of pesticides from agricultural runoff and drainage: A review. Environment International 75: 11-20.

2. Allam A, Tawfik A, El-Saadi, A Negm (2016) Potentials of using duckweed (Lemna gibba) for treatment of drainage water for reuse in irrigation purposes. Desalination and Water Treatment 57(1): 459-467.

3. Fleifle Amr, Tawfik Ahmed, Saaverda Oliver, Elzeir Mohamed (2013) Treatment of agriculture drainage water via downflow hanging sponge for reuse in agriculture. Water science and technology. Water supply 13(2): 403-412.

$\begin{array}{ll}\text { BIOMEDICAL } & \text { Assets of Publishing with us } \\ \text { RESEARCHES } & \text { - Global archiving of articles } \\ \text { - Immediate, unrestricted online access } \\ \text { ISSN: 2574-1241 }\end{array}$

